\title{
MOVIMENTO DA CONSCIÊNCIA E ETICIDADE: para uma localização da "filosofia do espírito" de 1803/04
}

\author{
Consciousness and ethical life: an attempt to \\ situate Hegel's philosophy of spirit (1803/04)
}

Erick Calheiros de Lima

Doutor em Filosofia pela UNICAMP. Pós-doutorando em Filosofia FAPESP/UNICAMP. São Paulo, SP - Brasil, e-mail: ericklima74@hotmail.com

\section{Resumo}

Pretende-se investigar como Hegel é conduzido ao vínculo entre eticidade e consciência. Primeiramente, o objetivo é compreender de que maneira a crítica à concepção contratualista de associação (1), tencionada ainda no Naturrechtsaufsatz, é direcionada, na "reconstrução" da comunidade proposta pelo System der Sittlichkeit, para uma teoria da consciência (2). Com isso, espera-se contribuir para a tese de que, se o recurso à consciência elimina os nexos constitutivos da subjetividade, a ausência dele aniquila o aferimento desta constituição. Finalmente, pretende-se considerar a construção do desenvolvimento da eticidade sobre uma teoria da consciência como tentativa de solucionar a exterioridade entre universal e singular, a qual constitui o ponto de partida do jus-racionalismo kantiano-fichteano (3). A perspectiva da eticidade como teoria da formação da consciência poderia propor um ponto de partida interessante para apreender a constituição recíproca das instituições e das capacidades prático-cognitivas da consciência individual, envolvidas na efetivação da liberdade comunicacional.

Palavras-chave: Eticidade; Consciência; Formação; Intersubjetividade; Comunidade. 


\section{Abstract}

This paper investigates how Hegel was led to connect ethical life and consciousness. Firstly, the aim is to consider how Hegel's critique of the contractarian conception of political association (1), prepared in the socalled Naturrechtaufsatz, is directed, in the reconstruction of the community in the System der Sittlichkeit, towards a consciousness theory (2). Based on this perspective, it can be taken into account that if the appeal to consciousness obstructs the ethical formation of subjectivity, the measurebility of it is also anihilated by the absence of this orientation. Finally, the paper considers the foundation of ethical life's development on a theory of consciousness as an attempt to solve the exteriority of universal and individual, which constitutes the starting point of Fichte's and Kant's account of the rational foundation of law. The perspective of ethical life, articulated as a theory of consciousness formation, could emphasize the reciprocal connection between the modern institutions and the cognitive-practical capacities of the individual which are involved in the actualization of communicative freedom.

Keywords: Ethical life; Consciousness; Formation; Intersubjectivity; community.

\section{Introdução}

No horizonte mais amplo de uma crítica à teoria do contrato social de extração hegeliana, em que se objeta a inobservância daqueles processos sociais que constituem, contíguas às instituições, as capacidades subjetivas ligadas à livre "agência", pressuposta pelo próprio contratualismo, o movimento de reconhecimento pode ser interpretado como a conexão fundamental entre universal e singular, a ser efetivada pelas instituições e práticas da eticidade (PATTEN, 1999, p. 104-105). Para além disso, uma avaliação da atualidade da concepção hegeliana do desenvolvimento da eticidade (HONNETH, 2000) exige que se pense se o "apriorismo" na dedução de suas instituições conta com qualquer correspondência no âmbito das instituições pressupostas pelo conceito pós-tradicional de justiça. Um primeiro passo seria investigar a plausibilidade da teoria da eticidade como teoria da formação de capacidades prático-cognitivas associadas à liberdade comunicativa e à justiça (HONNETH, 2004). 
Entretanto, para considerar potencialidades do vínculo entre teoria da eticidade e teoria da consciência, é necessário entrar em choque com a interpretação segundo a qual a introdução deste referido vínculo aniquila a possibilidade de que a teoria hegeliana da eticidade possa ser considerada em sua dimensão constitutiva das capacidades individuais para a efetivação da liberdade comunicativa (HONNETH, 1992, p. 90). Contra esta posição, pretende-se aqui, ainda que assaz preliminarmente, colher elementos que possam futuramente contribuir à tese de que, se a vinculação ao conceito de consciência elimina mesmo os nexos constitutivos da individualidade, a ausência deste aniquila o elemento de aferimento desta constituição. Nesse sentido, a perspectiva de uma teoria da eticidade como teoria da formação da consciência poderia propor um ponto de partida interessante para apreender a constituição recíproca das instituições e das capacidades prático-cognitivas da consciência individual.

Um dado fundamental acerca da teoria hegeliana da autoconsciência é sua herança fichteana. Dando continuidade à Grundlage des Naturrechts de Fichte, Hegel compreende a autoconsciência em sua processualidade, em sua gênese (LIMA, 2006, p. 16-17). Também seguindo Fichte, esta "genealogia da liberdade" (GADAMER, 1992) é vinculada, no âmbito da filosofia real, ao processo de reconhecimento recíproco. Portanto, perguntar pela origem do vínculo entre o movimento da consciência e a concepção de eticidade na obra de Hegel é desvelar o entrelaçamento entre eticidade e reconhecimento, ou antes, perscrutar que estruturas intersubjetivas de formação da autoconsciência são pressupostas e fomentadas pela noção de eticidade moderna.

Para diversos autores, desde as décadas de 60 e 70 do século XX, a teoria hegeliana da mediação intersubjetiva da liberdade tem sido considerada em seu potencial como princípio para uma filosofia prática e uma teoria social normativa (SIEP, 1979). Ainda mais recentemente (HONNETH, 2000), apesar da acirrada discussão acerca de em que medida a filosofia prática madura de Hegel permite o resgate de seu elemento intersubjetivo desenvolvido desde os textos de juventude, a construção de uma teoria da justiça que se beneficie do conceito hegeliano de reconhecimento é uma discussão em aberto - para alguns, ainda um rico filão no âmbito do discurso filosófico sobre a modernidade política (HONNETH, 2000).

Como diz Ludwig Siep, "o que torna a teoria do reconhecimento de Hegel interessante para a filosofia prática são sobretudo duas coisas: primeiramente, a ampliação do reconhecimento jurídico do respeito recíproco à liberdade da pessoa a formas 'solidárias' de consentimento ao bem-estar e à 'identidade' pessoal do outro. Em segundo lugar, a idéia de um modelo integrado de consentimento (Zustimmung), limitação e do deixar-livre (Freigabe). Se 
Hegel torna este 'movimento' o fio condutor de sua apresentação sistemática das formas de comportamento, construtos sociais (família, profissões e estado) e instituições (direito, administração e poderes públicos), então ele põe com isso, à disposição da filosofia prática - tanto sistemática quanto "concreta" -, um princípio talvez ainda hoje proveitoso" (SIEP, 1998, p. 27).

De acordo com esta vertente, que enfatiza a comunidade dos processos que originam a consciência singular e a intersubjetividade social, a consideração de uma teoria da justiça a partir dos processos mediadores de reconhecimento traz, em relação a uma abordagem mais individualista, a vantagem de levar em conta estruturas sociais vinculadas à socialização e à formação da personalidade, sem as quais a justiça não pode ser nem cultivada nem tematizada. Nesse sentido, mesmo que Hegel não tenha explorado todas as potencialidades de seu conceito de reconhecimento no quadro de sua filosofia social madura, o paradigma desenvolvido em sua teoria da intersubjetividade talvez contenha um profícuo ponto de partida para superar "dialeticamente" a unilateralidade de pontos de vista exclusivamente comunitaristas ou liberais (FORST, 1995) (HONNETH, 2000), justamente ao levar em conta elementos contextualistas envolvidos na formação das capacidades individuais.

Mas se Hegel pode ser ainda de serventia para uma teoria da justiça, antes precisa ser investigada a conexão entre a estruturação e o desenvolvimento de seu conceito de eticidade, por um lado, e processos intersubjetivos de formação que constituam os pressupostos da concepção moderna de justiça, de outro. O exame de tal questão requer, todavia, que se tenha antes uma exata compreensão da própria conexão entre eticidade e o reconhecimento, enquanto movimento da consciência.

Já se defendeu a idéia de que, na Fenomenologia, o reconhecimento tenha um alcance bem maior do que sua enunciação no capítulo "Autoconsciência" - e que, portanto, "historicamente... Hegel considere o conceito de reconhecimento efetivado numa determinada compreensão do direito moderno, da moralidade e da religião" (SIEP, 1998). Mas esta tese de leitura indica que o seu teor político não é e não pode ser aferido nos limites desta obra, pois ela não chega a discutir a estrutura das instituições políticosociais que tornariam efetivo o conceito de reconhecimento. No entanto, a Fenomenologia enuncia a estrutura normativa da formação recíproca das identidades individuais e de sua autoconsciência universal, cujo quadro de efetivação institucional é direcionado, pela Filosofia do Espírito da Enciclopédia, para a teoria da eticidade, onde Hegel pretende haver, ao menos em tese, uma constituição intersubjetiva da consciência-de-si, tanto ao nível da relação interpessoal, quanto entre indivíduo e instituições (entre "eu e nós"). 
O movimento do reconhecer na Enciclopédia revela um direcionamento ético-político do "puro conceito do reconhecer", enunciado no capítulo "autoconsciência" da Fenomenologia, e que contém, portanto, para o desenvolvimento do Hegel maduro, a estrutura normativa da concepção de intersubjetividade relevante para sua teoria da eticidade. A Enciclopédia incumbe a teoria da eticidade de apresentar o quadro institucional em que se efetiva a estrutura normativa do reconhecimento recíproco, isto é, do "puro conceito do reconhecer" da Fenomenologia. ${ }^{1}$ Afinal, segundo Hegel, a "eticidade é a idéia da liberdade", e com ela se trata do "conceito de liberdade tornado mundo existente e natureza da autoconsciência" (HEGEL, 2002, $\S 142$ ). É interessante perceber o duplo aspecto ao qual se refere a noção de eticidade: é, por um lado, um quadro institucional e normativo tecido intersubjetivamente, na medida em que provém do movimento fenomenológico da consciência; por outro lado, nos termos de uma moderna efetivação da liberdade, é a própria possibilidade de tematizá-la enquanto produto de relações concretas, as quais, justamente, efetivam a liberdade, tornando o mundo existente a natureza da autoconsciência. ${ }^{2}$

Em meio a este programa diferenciado em relação aos textos de Jena, sobretudo por "desconectar" o movimento do reconhecer da gênese da eticidade, Hegel empreende, na abertura do capítulo "Consciência-desi", uma "espécie de pré-designação conceitual da estrutura do reconhecimento" (SIEP, 2000, p. 4). Alguma indicação acerca da relação entre eticidade e o movimento da consciência é fornecida na Enciclopédia,

1 Trata-se da "forma paradigmática" do reconhecimento, à qual HEGEL, G. W. S. Fenomenologia do espírito. Petrópolis, RJ: Loyola, 1992 se refere explicitamente na fase madura de sua produção, como, por exemplo, nos adendos aos $\S 35$ e 57 das Grundlinien, a saber: os "desenvolvimentos fenomenológicos" da autoconsciência na Enciclopédia. Temse de observar que em HEGEL, G. W. S. Enciclopédia das ciências filosóficas. São Paulo: Loyola, 1995 se refere, nas Grundlinien, à teoria do reconhecimento tal como fora desenvolvida na versão publicada em 1817 da Enciclopédia, a assim chamada Heidelberger Enziklopädie. No entanto, esta versão da teoria do reconhecimento não apresenta modificações decisivas com relação à Berliner Enzyklopädie de 1830, a qual fornece uma versão melhor decantada e pormenorizada do que a obra anterior.

2 Posta nestes termos, trata-se aqui da posição segundo a qual Hegel tenha antecipado a distinção habermasiana entre comunicação cotidiana e discurso. Para uma consideração da questão, proposta pelo próprio Habermas, ver suas colocações acerca da relação entre moralidade e eticidade, as quais se relacionam intimamente com sua teoria da modernidade enquanto processo que torna possível a moral pós-tradicional, que tem de tematizar a vulnerabilidade dos processos de socialização. 
e Hegel parece evidenciá-la pela expressão "reaparecer [Wiedererscheinen] universal da consciência-de-si" (Dies allgemeine Wiedererscheinen des Selbstbewußtseins) (HEGEL, 1995, §436). ${ }^{3}$ Este reaparecer pode ser interpretado como um refletir do si pelo outro, uma mútua afirmação intersubjetiva (WILLIAMS, 1997, p. 91). Para Hegel, esta consciência universal, na qual as consciências-de-si reaparecem numa união amalgamada pelo conhecimento afirmativo recíproco de si no outro, constitui "a forma da consciência da substância de toda espiritualidade essencial (die Form des Bewusstseins der Substanz jeder wesentlichen Geistigkeit), da família, da pátria, do Estado, assim como de todas as virtudes, do amor, da amizade, da bravura, da honra, da glória” (HEGEL, 1995, §436).

$\mathrm{Na}$ medida em que o resultado do processo de reconhecimento recíproco é este "aparecer do substancial" (Erscheinen des Substantiellen), o aparecimento mesmo do elemento espiritual como objetividade e ser-aí determinado, o movimento do reconhecimento pode ser compreendido como "gênese fenomenológico-existencial do espírito objetivo" (WILLIAMS, 1997, p. 91). Afora isso, Hegel compreende, na Enciclopédia, em contrapartida à efetivação da liberdade enquanto conexão substancial, o reconhecimento como conexão fenomênica desta configuração da liberdade, seu aparecimento: "a liberdade, configurada em efetividade de um mundo, recebe a forma da necessidade, cuja conexão substancial é o sistema das determinações da liberdade, e cuja conexão fenomênica é como potência, o ser-reconhecido, isto é, seu vigorar na consciência" (HEGEL, 1995, §484). Ser-reconhecido é a expansão da autoconsciência para além de si mesma, sobre a alteridade, e da alteridade sobre si: é, portanto, a constituição de um mundo em e para a autoconsciência, vigorar, aparecimento da vigência da conexão substancial no elemento prático da autoconsciência.

Se Hegel permanece, em sua obra madura, fiel às intuições de juventude acerca da constituição intersubjetiva da eticidade e de suas decorrências na formação das estruturas de personalidade pressupostas por um conceito moderno de justiça, é necessário que se procure compreender como se estabelece em sua obra o vínculo entre eticidade e movimento da consciência, mesmo que uma tal empreitada revele que a teoria definitiva da eticidade sofre

3 Hegel utiliza o termo Wiederscheinen. Na tradução oferecida por Paulo Meneses (p. 207), consta o termo original Widererscheinen, traduzido como "aparecer contrastante". Já a edição Theorie Werkausgabe da Suhrkamp traz o termo Wiedererscheinen, o qual estamos traduzindo por "reaparecer". 
pela ausência de tais elementos (THEUNISSEN, 1982), os quais respondem, decerto, por parte inestimável da formação social e individual de uma comunidade política em que se decantam as principais intuições e pontos de vista vinculados à justiça (HONNETH, 1992).

Nesse sentido, procuraremos refletir, a seguir, partindo da primeira explicitação de um conceito de eticidade compreendido processualmente (LIMA, 2007, p. 36-37), oferecida pelo System der Sittlichkeit, como Hegel pretende vincular, ainda na obra "préfenomenológica" de Jena, o problema intersubjetivo e processual da eticidade ao movimento da consciência, o que nos levará à sua primeira tematização rigorosa dos conceitos de espírito e consciência. Para isso, teremos que perseguir este fío condutor até o vínculo estabelecido por Hegel entre a gênese intersubjetiva da eticidade, fundada no conceito de reconhecimento, e a teoria da consciência, vínculo que caracteriza parcialmente o System der Sittlichkeit, e substancialmente a filosofia do espírito do Jenaer Systementwürfe 1803/04.

\section{Intuição da totalidade ética no system der sittlichkeit}

Dissemos que o System der Sittlichkeit apresenta-se como a primeira tematização do desenvolvimento conceitual da eticidade. Embora não possamos insistir aqui neste vínculo, ${ }^{4}$ temos de recorrer justamente a esta concepção processual para compreender sua antecipação do direcionamento da constituição da eticidade pelo conceito de consciência. Tal antecipação é visível na passagem da "parte negativa" do texto, a qual discute o crime e a justiça vingativa, para a parte destinada a expor a eticidade comunitária propriamente dita.

Como mostrou Honneth seguindo Wildt, a exasperação do conflito jurídico numa luta por honra torna claro que, do ponto de vista de uma articulação

4 Isto nos levaria a uma investigação acerca da relação entre o conceito de eticidade, desenvolvido no System der Sittlichkeit, e sua relação com o âmbito jurídico-econômico considerado sob o título de "eticidade relativa" no Naturrechtsaufsatz. Acerca disso e das influências fichteanas recebidas por Hegel, tomamos a liberdade de referir a outro trabalho nosso (LIMA, E. C. Direito e intersubjetividade: eticidade moderna em Hegel e o conceito fichteano de reconhecimento. 2006. 293 f. Tese (Doutorado em Filosofia) UNICAMP, Campinas, 2006. p. 23). 
entre a intersubjetividade excludente e a participativa, ${ }^{5}$ somente a demonstração da incompletude de formas estritamente jurídicas de existência social pode engendrar o teor intersubjetivo sobre o qual uma comunidade ética pode se formar. Não é por acaso, portanto, que Hegel sublinha que somente a constituição intersubjetiva do ser-um do indivíduo e da totalidade é capaz de preencher a condição de uma constituição do todo imanente às partes, o que, justamente, diferencia a compreensão hegeliana de comunidade de seu concorrente contratualista. ${ }^{6}$

Ao ser o povo a indiferença viva e ao ser toda a diferença natural nadificada, o indivíduo intui-se em cada um como a si mesmo. Ele alcança a suprema sujeito-objetividade. E esta identidade de todos é justamente, por meio disso, não uma igualdade abstrata, uma [igualdade] da cidadania, mas uma [igualdade] absoluta, e uma [igualdade intuída na consciência empírica, uma [igualdade] que se apresenta na consciência da particularidade. O universal, o espírito, é, em cada um e para cada um, ele mesmo, na medida em que ele é singular. Ao mesmo tempo, este intuir e ser-um são imediatos, o intuir não é nada além do que o pensamento. (HEGEL, 2002, p. 49).

5 A peculiar inserção do conceito de luta no System der Sittlichkeit, caracterizada pela reunião de níveis conflito em uma expansão contínua do universal abstrato, os quais não intermedeiam o próprio reconhecimento, é atribuído por Honneth - em conexão com sua interpretação acerca do aristotelismo de Hegel, que forja sua compreensão do estofo intersubjetivo primordial que tece a "eticidade natural" e cuja abrangência será tornada absoluta pela liberdade negativa - à utilização do método de subsunção e à intenção de Hegel de fazer valer seu Ansatz contra a teoria hobbesiana do estado de natureza (HONNETH, A. Kampf um Anerkennung: zur Moralischen Grammatik sozialer Konflikte. Frankfurt am Main: Suhrkamp, 1992. p. 35-36). Entretanto, esta peculiaridade pode ser reconduzida a uma necessidade socioteórica premente para Hegel, a qual, entretanto, ele expõe de uma maneira aparentemente ocasional na obra de 1802: o arcabouço intersubjetivo da existência social dos indivíduos é compreendido como uma articulação entre uma forma inclusiva e uma excludente de relação intersubjetiva, de maneira que a sucessão dos conflitos, que ora negam um, oram negam outro aspecto deste feixe de relações primárias.

6 Hegel desenvolve esta relação na forma de uma contraposição entre a comunidade enquanto totalidade dialética e a sociedade enquanto "agregado" concebido na base de um atomismo social. "Há que se conhecer a identidade desta intuição e da idéia. No povo está posta formalmente em geral, a saber, a relação de uma multidão de indivíduos, não uma multidão carente-de-relação (eine beziehungslose Menge), nem uma simples maioria. Aquele [conceito], uma multidão não põe, em geral, uma relação que está na eticidade, a subsunção de todos sob um universal, o qual teria para a consciência dela realidade, que seria um com eles, e que tivesse poder e violência sobre eles; mas antes a multidão é singularidade absoluta, e o conceito da multidão, ao serem eles um, é a abstração deles que lhes é estranha, exterior a eles" (HEGEL, G. W. F. System der Sittlichkeit [Critik der Fichteschen Naturrechts]. Hamburg: Felix Meiner, 2002, p. 49). 
Intuição dos indivíduos uns nos outros constitui o povo como indiferença viva, ao passo que a intuição do mesmo na consciência empírica responde pela imanência desta constituição. ${ }^{7}$ Os fenômenos da auto-exclusão do singular demonstram, gradual e universalmente, a dependência da plena individualização em relação ao todo social e, portanto, à socialização que forma a comunidade: eles estabelecem, na forma de uma progressiva ruptura e intensificação de relações intersubjetivas, o unívoco paralelismo entre individualização e socialização.

A possibilidade da absoluta negação da eticidade natural torna as potências da eticidade relativa incapazes de garantir a efetivação da eticidade nos costumes de um povo. "A natureza absoluta não está, em nenhuma delas, numa figura espiritual (Geistesgestalt): nem a família, nem as potências subordinadas, ainda muito menos o negativo, são éticos" (HEGEL, 2002, p. 47). Por isso, a realização da unidade absoluta da inteligência implica a recondução dos contrapostos à unidade. "A eticidade tem de ser, com a completa nadificação da particularidade e da identidade relativa, do que unicamente a relação natural (Naturverhältnis) é capaz, identidade absoluta da inteligência" (HEGEL, 2002, p. 47). Assim, Hegel oferece, inicialmente, uma visão retrospectiva da exposição total da obra sublinhando que em nenhum dos elementos anteriores, quer seja na unidade relativa do reconhecimento da liberdade negativa da pessoa, quer seja na unidade indiferente da família, encontra-se a natureza absoluta numa forma espiritual, o que significa que as "figuras" desenvolvidas até este ponto não são ainda genuinamente éticas. ${ }^{8}$

7 Segundo Honneth, Hegel procura salientar, com a fórmula da intuição de si mesmo no outro - pela qual explicita a relação intersubjetiva própria do âmbito da eticidade no System der Sittlichkeit, a qual é repetida, anos mais tarde, na Fenomenologia-, "uma forma da relação recíproca entre os sujeitos que é superior à forma meramente cognitiva", que caracteriza para ele o reconhecimento jurídico. Peculiar a esta forma de relação intersubjetiva é o fato de que tangencia o elemento afetivo, o que leva Honneth a caracterizá-la através do conceito de solidariedade. Desta maneira, Honneth acaba abordando a relação entre os tipos de intersubjetividade, algo presente para Hegel desde Frankfurt, mas que, na análise de Honneth, obtém apenas uma importância episódica. Os elementos solidários contidos na intuição de si no outro "devem fornecer, manifestamente, a base comunicativa sobre a qual os indivíduos, isolados uns dos outros pela relação de direito, podem, mais uma vez, se encontrar no quadro mais abrangente de uma comunidade ética" (HONNETH, 1992, p. 44).

8 Hegel comenta, na introdução à eticidade, esta insuficiência do ponto de vista da particularidade, considerada de ambos os lados, tanto da particularidade como tal, como da universalidade abstrata (HEGEL, G. W. F. System der Sittlichkeit [Critik der Fichteschen Naturrechts]. Hamburg: Felix Meiner, 2002. p. 47). 
Digno de nota é que Hegel tem inicialmente diante dos olhos uma constituição intersubjetiva da eticidade, o que ele deixa transparecer, não obstante o nítido apelo à concepção aristotélica da pólis, na oposição à relação intersubjetiva na família: "A intuição está, ao mesmo tempo, em relação, o intuir-se real e objetivamente do indivíduo no outro está preso a uma diferença. O intuir na mulher, na criança e no escravo não é nenhuma igualdade absoluta perfeita (vollkommen). Ela permanece uma [igualdade] interior, não engendrada para fora (nicht herausgeborene), impronunciada. Há uma insuperabilidade (Unüberwindlichkeit) do conceituar da natureza dentro dela" (HEGEL, 2002, p. 47). Ainda que implicitamente, é em vista da exigência intersubjetiva de uma "intuição indiferente" do indivíduo no outro que Hegel define o escopo sistemático de uma "unidade da inteligência" capaz de indiferenciar a "unidade da natureza" atingida na família.

A identidade absoluta da natureza tem de ser acolhida na unidade do conceito absoluto e de estar presente na forma desta unidade: uma essência clara e, ao mesmo tempo, absolutamente rica, ser-objetivo plenamente acabado e intuir do indivíduo em um estranho, portanto, a suspensão da determinidade e configuração naturais, completa indiferença da fruição de si. (HEGEL, 2002, p. 47).

Hegel articula, então, uma constituição intersubjetiva do Einssein, do ser-um entre o indivíduo e o todo ético, mostrando que a intuição dele em seu outro é o elemento originário da unidade ética. Justamente a suspensão da configuração natural e de determinidades, necessária a esta gênese, é associada ao movimento da inteligência enquanto "conceito absoluto". "Desta maneira, o conceito infinito é somente pura e simplesmente um com a essência do indivíduo I, e o mesmo [está] presente em sua forma como inteligência verdadeira. Ele é verdadeiramente infinito, pois todas as suas determinidades estão nadificadas" (HEGEL, 2002, p. 47-48). Na identidade absoluta da inteligência, a eticidade absoluta chega a si mesma, suspende suas potências naturais como natureza inorgânica, e alcança a unidade do conceito absoluto em uma configuração espiritual (Geistesgestalt). Nesta configuração espiritual da eticidade, as determinidades da natureza ética são elevadas a um nível mais amplo de efetividade social, assim como a unidade formada por ela e sua suspensão no 
crime estabelecem, como fundamento da divisão do sistema da eticidade, a possibilidade da liberdade pura do indivíduo. ${ }^{9}$

Para Hegel, o conceito absoluto acolhe em si a determinidade natural e a configuração da eticidade absoluta e também a nadifica. Com a negação da eticidade absoluta como natureza, ela surge em configuração espiritual, "é conduzida ao conceito absoluto enquanto particular que, a partir de si mesmo, forma, com as formas da eticidade apreensíveis através da intuição, uma unidade absoluta" (KIMMERLE, 1970, p. 237).

Esta forma espiritual, a qual prefigura o conceito fundamental que, no lugar do conceito inteligência, funcionará como estrutura nos sistemas subseqüentes da filosofia prática, caracteriza-se como identidade absoluta da inteligência, em face da qual tudo aquilo que se acha ainda permeado pela particularidade e pela identidade relativa própria à relação natural se torna insuficiente. ${ }^{10}$ É nesse sentido que Hegel compreende a eticidade genuína e absoluta

9 Kimmerle vê aqui a incongruência de que o System der Sittlichkeit deveria ter sido elaborado desde o início como o desdobramento deste princípio de possibilidade da liberdade pura do indivíduo, e não ter tomado como ponto de partida princípios de conhecimento como intuição e conceito absoluto. (KIMMERLE, H. Das Problem der Abgeschlossenheit des Denkens. Hegels "System der Philosophie" in den Jahren 1800-1804. Bonn: H. Bouvier, 1970, p. 239) Neste sentido, a percepção deste elemento imanente à temática da eticidade poderia ser interpretado como motivador recôndito para um afastamento em relação ao arcabouço metodológico tomado de Schelling em direção ao realinhamento com o bewusstseintheoretischer Ansatz de Fichte, o qual foi notado sobretudo por RIEDEL, M.; Hegels K. des N. In: RIEDEL, M. Studien zu Hegels Rechtsphilosophie. Frankfurt am Main: Suhrkamp, 1969. e WILDT, A. Autonomie und Anerkennung. Hegels Moralitätskritik im Lichte seiner Fichte-Rezeption. Stuttgart: Klett-Cotta, 1983.

10 Esta insuficiência das formas societárias prévias, localizadas ao nível de uma identidade relativa, indica uma importante modificação posterior de Hegel. A partir dos Jenaer Systementwürfe, há uma reconsideração da classificação de tais estágios como estritamente não-éticos, ao não satisfazerem o critério da absoluta indiferença: Hegel passa a compreendê-los como integrados à eticidade absoluta na qualidade de momentos aos quais cabe um "Recht", na acepção amplamente utilizada nas Grundlinien. (SCHNÄDELBACH, H. Hegels Praktische Philosophie: ein kommentar der texte in der reihenfolge ihrer entstehung. Frankfurt am Main: Suhrkamp, 2000. p. 98-99). De acordo com Schnädelbach, isto se faz acompanhar pela substituição do conceito de povo pelo de estado, o qual passa a abranger, enquanto unidade individual do ético, todos os momentos da eticidade natural, relativa e negativa. Associada a isso está também a inserção do estado na esfera do espírito objetivo e a correspondente separação entre espírito absoluto e objetivo, o que, embora fomente o esvaziamento da concepção hegeliana de intersubjetividade em nome da monarquia constitucional, assimilada ao movimento de efetivação da singularidade conceitual da idéia liberdade na "personalidade do estado", desobriga o estado de ser a manifestação imediata do absoluto. 
como identidade absolutamente indiferente de intuição intelectual e intuição empírica, da essência universal e do indivíduo, do fazer universal e do fazer individual. "Na eticidade o indivíduo é, portanto, de uma maneira eterna. Seu ser e fazer empíricos são um pura e simplesmente universal; pois não é o individual que age, mas antes o espírito absoluto e universal nele" (HEGEL, 2002, p. 48).

Trata-se, portanto, do resgate do enunciado seminal do System der Sittlichkeit, segundo o qual o povo é a intuição desta idéia de eticidade cujo conceito é uma multiplicidade de indivíduos. "A intuição desta idéia da eticidade, [...] a forma na qual ela aparece a partir do lado de sua particularidade, é o povo" (HEGEL, 2002, p. 50), uma intuição que é absoluta, "porque ela é pura e simplesmente objetiva, todo ser-singular e sensação está nela exterminado e ela [é] intuição, porque ela está na consciência. O conteúdo dela [da intuição E.C.L] é absoluto, porque ele é o eterno e está livre de todo subjetivo" (HEGEL, 2002, p. 50). Aqui não é somente o prenúncio do ser-reconhecido, enquanto vigorar "fenomenológico" da estrutura substancial das determinações da liberdade na consciência, que se delineia. $\mathrm{O}$ descentramento das perspectivas particulares, o aplainamento das unilateralidades vinculadas à ênfase particularista das outras potências e, enfim, o direcionamento ético da subjetividade, que caracterizam, em toda filosofia hegeliana, as perspectivas da eticidade efetiva e da autoconsciência universal, são associados, no System der Sittlichkeit, com o círculo traçado desde a enunciação de sua pressuposição fundamental; pois, se a obra tem seu ponto de partida na contraposição do singular ao mundo como objeto da satisfação mediada pelo trabalho, aqui, diz Hegel, "toda a relação à carência e aniquilar é suspensa, e o prático, que começa com o aniquilar do objeto, passou para seu contrário, para a aniquilação do subjetivo, de tal maneira que o objetivo é a identidade absoluta de ambos" (HEGEL, 2002, p. 50).

\section{Conexão entre eticidade e consciência na primeira fase em Jena}

Embora não se possa aqui insistir neste ponto, há que se admitir que, ainda que implicitamente, Hegel investiga, ainda em Frankfurt e no início do período de Jena, a conexão entre eticidade e intersubjetividade (LIMA, 2006, p. 68-69). No System der Sittlichkeit, por meio de um resgate não simplesmente programático, como no Naturrechtsaufsatz, da tese aristotélica da "anterioridade da pólis", Hegel estabelece, em sua teoria do desenvolvimento da eticidade, a conexão entre a liberdade individual, 
radicalizada pela filosofia transcendental, e a formulação de um quadro institucional comunitário ${ }^{11}$ no qual aquela liberdade pode encontrar sua efetivação adequada. Entretanto, é somente na segunda metade do período de Jena que Hegel torna-se plenamente capaz de implementar este projeto, o qual, a partir de 1805/06, estabelece a feição madura de sua filosofia política.

Ainda no System der Sittlichkeit, foi a reformulação inspirada em Fichte do ponto de partida aristotélico, bem como a "dinamização hobbesiana" da teoria fichteana do reconhecimento, ${ }^{12}$ movimentos vinculados à reconstituição do conceito hegeliano de intersubjetividade trazido de Frankfurt, que permitiram a Hegel precisar a tarefa fundamental de sua filosofia social. Por outro lado, é somente na medida em que, a partir de 1803, o conceito de reconhecimento, aglutinando todos estes desvios e reestruturações, é vinculado à formulação de uma teoria da consciência, que esta tarefa é implementada de uma maneira que se torna, aos olhos de Hegel, metodologicamente exitosa. Eis por que o conceito

11 Siep compreende esta tarefa, sobretudo, como uma dupla necessidade: primeiramente, a necessidade de superar a destruição kantiana da filosofia prática clássica; em segundo lugar, o desafio de ultrapassar o abismo entre a ética e a crítica da sociedade por meio de uma teoria das instituições. Para Siep, é a esta dupla necessidade que se dirige o vínculo entre reconhecimento e teoria da consciência (SIEP, L. Anerkennung als Prinzip der Praktischen Philosophie. Freiburg/München: Alber, 1979).

12 Segundo Honneth, é a eticidade natural, enquanto fundamento natural da socialização humana, que permite afugentar o atomismo do direito natural moderno: compreendida teleologicamente segundo o conceito aristotélico de natureza, representa o germe da idéia de comunidade a ser plenamente desenvolvido na eticidade política (HONNETH, A. Kampf um Anerkennung: zur moralischen Grammatik sozialer Konflikte. Frankfurt am Main: Suhrkamp, 1992, p. 26). Hegel interpõe, então, entre ambos os estágios "a reconfiguração e a ampliação das formas iniciais da comunidade social na direção de relações mais abrangentes de interação social" (HONNETH, 1992, p. 27). Os fenômenos do crime têm de anular, por meio de recorrentes negações de relações intersubjetivas primárias, "unilateralidades e particularizações" que ainda permeiam determinados níveis de coexistência social. Com efeito, Hegel forneceria, para Honneth, com sua doutrina da eticidade natural, a compreensão do teor normativo do fundamento natural da coexistência, de maneira que deste núcleo surgiria, por meio da concepção da "diferenciação" imposta pela atitude excludente do crime, uma progressiva intensificação dos "laços comunitários" e, ao mesmo tempo, da autonomia e da identidade individuais. Neste empreendimento, concorrem, segundo Honneth, duas tendências: uma reformulação do modelo fichteano a fim de reconstruir intersubjetivamente o estofo societário compreendido aristotelicamente; e uma reformulação do conceito hobbesiano de luta que tenciona dinamizar o modelo de Fichte no sentido da introdução da ampliação do quadro societário pré-estatal. 
de Vereinigung ${ }^{13}$ decantado especulativamente nos textos publicados de Jena, forma o protótipo para o conceito de reconhecimento nos textos não-publicados deste período. A unificação é o medium no qual Hegel pretende reestruturar tanto a noção kantiana de autonomia, quanto a noção de uma liberdade intersubjetivamente mediada, formulada segundo a dicotomia fichteana entre autoconsciência pura e consciência empírica, como ainda a exterioridade mútua destes registros; de maneira que o reconhecimento parece sustentar, enquanto movimento de unificação, o projeto jenense de Hegel de uma "renovação da filosofia prática" na forma de uma "superação da separação entre ética e política" (SIEP, 1979, p. 146-147). A partir de 1803, Hegel delega ao processo de reconhecimento a tarefa de construir uma conexão de mútua implicação entre a liberdade singular e as instituições sociais unicamente pelas quais esta liberdade se realiza concretamente. Trata-se, portanto, de uma genuína "teoria da efetivação da liberdade em instituições, a qual disponibiliza um critério para a crítica das instituições" (SIEP, 1979, p. 154).

Na implementação do programa do Naturrechtsaufsatz no System der Sittlichkeit, uma tal simbiose entre autonomia individual e sua realização institucional supõe justamente um mútuo relacionamento de processos de individualização e socialização em uma teoria que explique como a progressiva formação de instituições, capazes de efetivar a liberdade, vincula-se à progressiva aquisição, por parte do indivíduo, de uma autocompreensão correspondente a níveis desta socialização institucional (HONNETH, 1992, p. 27). No System der Sittlichkeit, esta exigência se traduz na necessidade de pôr como ponto de partida, ao menos da apresentação, o singular no ambiente de sua existência natural, embora tal texto lance mão da pressuposição da eticidade enquanto povo (HEGEL, 2002, p. 3).

É justamente no sentido da eliminação desta pressuposição que os instigantes Jenaer Systementwürfe fundamentam a teoria do reconhecimento sobre uma teoria da consciência, de maneira que o período de Jena caracterizase, sobretudo, pela progressiva tomada de consciência de que o projeto de mediação entre a filosofia prática moderna e a filosofia política clássica depende

13 Ainda em Frankfurt, Hegel percebera que somente no "quadro socioinstitucional" - nesta época, uma religião do povo intersubjetivamente constituída por meio do amor -, a individualidade modernamente engendrada encontraria condições de efetivação. Entretanto, com o conceito de amor enquanto Vereinigung, compreendido em sua dimensão horizontal e vertical, Hegel chega à intuição de que a liberdade do indivíduo se localiza no âmbito da unificação, a qual unicamente pode tornar positivo aquilo que de outra maneira somente poderia se deixar sentir como limitação (SIEP, 1992). 
de um processo de auto-efetivação da consciência no quadro institucional da consciência universal e que não seja, portanto, simplesmente um pressuposto exterior à consciência, elevada, em circunstâncias modernas, à condição incontornável da realização plena da liberdade.

Pode parecer temerário continuar a sustentar a articulação de processos de individualização e socialização na teoria hegeliana da eticidade após a vinculação do processo de reconhecimento ao autodesenvolvimento da consciência, principalmente após Honneth ter pretendido demonstrar a quebra do teor individualizante do desenvolvimento da eticidade pela assimilação dos seus estágios ao automovimento do espírito. Entretanto, recorremos aqui a uma hipótese de Habermas. Este parece não partilhar da posição de Honneth de que os esboços de sistema de Jena, embora continuem a manter a força de seu viés socializador, sacrifiquem seu nexo individualizante com a adesão à teoria da consciência (HABERMAS, 1999) e o conseqüente afastamento em relação ao ponto de partida aristotélico do System der Sittlichkeit, segundo o qual a progressiva intensificação dos laços sociointegradores possui como contrapartida um processo de individualização e sofisticação da relação a si do eu graças à prévia imersão do indivíduo no estofo originário de relações comunicacionais que caracteriza a eticidade natural. ${ }^{14}$

Creio que seja possível aglutinar elementos que ponham em dúvida a visão de que Hegel teria compensado sua adesão à teoria da consciência com uma renúncia ao intersubjetivismo em sentido forte que residia no recurso ao ponto de partida "teórico-comunicativo" aristotélico. ${ }^{15}$ Habermas estabelece,

14 Para Honneth, com o apelo à teoria da consciência a partir de 1803, Hegel eliminou do conceito de natureza todo o seu "significado ontologicamente abrangente" (HONNETH, 1992, p. 48), o qual passa apenas a significar o contraposto absoluto do espírito, isto é, a natureza física e préhumana. Honneth vê nisso a estruturação teórica da esfera da eticidade entregue ao processo de reflexão do espírito, o que já aponta para a sistemática definitiva. Embora desde 1802 Hegel compreenda o movimento do reconhecimento sempre como um meio de socialização e formação comunitária da consciência universal pelo descentramento das perspectivas excessivamente individuais, somente o System der Sittlichkeit mune este movimento com a capacidade de gerar individualização, isto é, "aumento das capacidades do eu" (HONNETH, 1992, p. 51).

15 Para Wildt, o fato de, a partir de 1803, a luta não se originar mais de um crime contra um estágio prévio de relação comunicacional entre os indivíduos, não significa que, aliada à sua capacidade socializadora e geradora de normas, a teoria do reconhecimento perca, como quer Honneth, sua capacidade de intensificação das capacidades individuais. Para Wildt, a diferença da teoria do reconhecimento em sua nova versão não está em que ela subtrai a lesão ao outro de qualquer vinculação normativa, mas que "ela, seguindo o atalho que passa pelo conceito de consciência e a experiência da mesma em relação à própria morte, relaciona a temática do crime explicitamente à problemática da identidade do eu” (WILDT, 1983, p. 341). 
partindo de Hegel, uma vinculação das mais importantes entre a normatividade e os processos de socialização e individualização. Para Habermas, o que notabiliza a concepção hegeliana do eu em face dos seus predecessores idealistas é justamente sua compreensão dele, plasmada pela estrutura lógico-especulativa do conceito, como unidade imediata de universalidade e singularidade, pela qual Hegel vai além do eu kantiano enquanto unidade originária da apercepção, que representa a experiência, fundamental para a filosofia da reflexão, da identidade do eu na autoreflexão, a auto-experiência do sujeito cognoscente proporcionada por sua capacidade de absoluta abstração. Este conceito de unidade espiritual permite que os singulares identifiquem-se uns com os outros e, ao mesmo tempo, percebam-se como não-idênticos. "A percepção originária de Hegel consiste em que o eu, enquanto autoconsciência, somente pode ser compreendido quando é espírito, isto é, quando ele passa da subjetividade à objetividade de um universal, em que, sobre a base da reciprocidade, os sujeitos, que se sabem como não idênticos, são unificados" (HABERMAS, 1974, p. 790).

Habermas relaciona este conceito de unidade espiritual justamente a dois momentos: o momento da normatividade intersubjetivamente engendrada e o momento dos processos de socialização e individualização. Sobre a primeira conexão, diz Habermas: "porque Hegel compreende autoconsciência a partir da conexão interativa do agir complementar - a saber, como resultado de uma luta por reconhecimento -, ele percebe o conceito kantiano da vontade autônoma... como uma abstração peculiar da relação ética dos singulares que se comunicam" (HABERMAS, 1974, p. 790). Esta conexão da unidade espiritual com a idéia de uma normatividade intersubjetivamente engendrada, a relação ética, torna-se extremamente importante para as premissas da teoria da ação comunicativa e, na medida em que é capaz de "contextualizar" uma ética de tipo kantiano, também para a concepção seminal da ética do discurso (HABERMAS, 1974, p. 794).

Mas vejamos mais de perto o estabelecimento do vínculo entre desenvolvimento da eticidade e teoria da consciência. No Naturrechtsaufsatz, a crítica hegeliana às insuficiências do direito natural moderno desemboca numa tese de que a radicalização das premissas atomistas da filosofia prática moderna é incapaz - mesmo quando, como em Fichte, torna a relação comunitária condição da liberdade singular - de fundamentar a prioridade da comunidade, porque aponta para uma cisão entre consciência pura e consciência individual (HEGEL, 1970, p. 469-470). A compreensão da comunidade política pautada pela ênfase absoluta numa consciência pura da liberdade apartada da natureza conduz Hegel a uma compreensão da eticidade como unidade indiferente da consciência pura e da consciência empírica (HEGEL, 1970, p. 458), ser-um dos indivíduos e do povo. 
Em busca da implementação deste programa, o System der Sittlichkeit parte do indivíduo imerso em sua socialização pré-estatal, mas procura compreender a identidade entre indivíduo e povo como teleologicamente inserida no conceito de natureza. Mas Hegel não é capaz ainda de obter a eticidade absoluta e o Einssein de consciência universal e consciência individual apenas como um desdobramento da perspectiva individual, pois o próprio ponto de partida não é ele próprio idêntico ao princípio moderno da consciência ou da subjetividade, mas sim uma concepção sobre os elementos implícitos na imersão do indivíduo na natureza. ${ }^{16}$ É nesse sentido, portanto, que o desenvolvimento do conceito hegeliano de eticidade no System der Sittlichkeit não corresponde plenamente nem à necessidade, exposta no Naturrechtsaufsatz, de que a singularidade seja suspensa pela própria liberdade singular, nem àquela diretriz, definida na Differenzschrift, segundo a qual o sistema filosófico deve se dirigir à comprovação, para a consciência, da unidade entre consciência universal e consciência singular. ${ }^{17}$ Porém, isso ainda não quer dizer que, embora a letra da

16 Contestamos a tese de Siep de que Hegel ainda não foi capaz de compreender a suspensão da eticidade relativa e da liberdade pura "enquanto um desenvolvimento necessário cujo princípio seja ele mesmo visível na eticidade relativa" (SIEP, 1992, p. 163). Não se trata somente de visibilidade, já que, partindo da concepção da intuição da eticidade como povo, Hegel parece antes direcionar sua compreensão do ponto de partida da exposição, o indivíduo contraposto ao mundo como ambiente de satisfação de suas carências, a fim de obter a intuição pressuposta. O problema é antes que, se o programa hegeliano é de mediação, não parece claro então que um conceito teleológico de natureza possa ser plenamente reconduzido ao conceito kantianofichteano de liberdade da consciência.

17 "O absoluto deve ser construído para a consciência, isto é a tarefa da filosofia" (HEGEL, G. W. F. Werke in 20 bände. Frankfurt am Main: Suhrkamp, 1970, II, p. 24). A execução da tarefa da filosofia, compreendida ainda em termos de uma síntese especulativa entre intuição e reflexão, pode ser vinculada à separação entre consciência pura e empírica. "A reflexão filosófica é condicionada, ou a intuição transcendental vem à consciência pela livre abstração de toda multiplicidade da consciência empírica; e, nesta medida, ela é um subjetivo... Para apreender a intuição transcendental de maneira pura, ela [a reflexão E.C.L] tem ainda de abstrair deste subjetivo, [fazer com] que ela não seja para a mesma, enquanto fundamentação da filosofia, nem subjetiva nem objetiva, nem autoconsciência contraposta à matéria, nem matéria contraposta à autoconsciência, mas identidade absoluta, nem subjetiva, nem objetiva: pura intuição transcendental... A contraposição da reflexão especulativa não é mais um objeto e um sujeito, mas antes uma intuição transcendental subjetiva e uma intuição transcendental objetiva, aquela eu, esta natureza. Que estes dois contrapostos - eles se denominam agora eu e natureza, autoconsciência pura e empírica, conhecer e ser, pôr-se-a-si-mesmo e contrapor, finitude e infinitude - sejam postos, ao mesmo tempo, no absoluto, nesta antinomia a reflexão comum não enxerga nada além da contradição, apenas a razão [enxerga] nesta absoluta contradição a verdade" (HEGEL, 1970, II, p. 115). 
exposição esbarre no excessivo aristotelismo, o espírito dela não reconheça a validade de tal diretriz, como atestam determinadas considerações sobre a Ständelehre no Naturrechtsaufsatz, despidas de sua concretude pela inspiração na República de Platão e direcionadas aos termos de uma incipiente teoria da consciência (HEGEL, 1970, II, p. 499-505).

A partir do primeiro esboço de sistema de Jena, escrito em 1803/ 04, Hegel começa a se afastar da orientação schelliniana de uma concepção de eticidade direcionada pelo conceito de natureza, orientação à qual se conecta também seu aristotelismo jenense (DÜSING, 1994). ${ }^{18}$ Tal desvio parece completar aquela diretriz, mencionada por Hegel no Naturrechtsaufsatz, segundo a qual o espírito é mais elevado do que a natureza. ${ }^{19}$ É a partir de 1803/1804 que a natureza passa a ser compreendida de maneira apartada do processo de vir-asi do espírito, isto é, de tal forma que o espírito passa a ser compreendido, em primeira instância, como negação da natureza, como "recolhimento infinito do universo (a)dentro de si", tendo seu ponto de partida na "idealidade absoluta da mesma" (HEGEL, 1970, II, p. 502).

Nesse sentido, a partir de 1803/1804, a filosofia prática passa a integrar aquela parte do sistema que constrói o retorno do absoluto enquanto espírito a partir de sua exteriorização na natureza. Nesta nova diretriz sistemática, em que surge a prefiguração da apresentação enciclopédica, cabe à filosofia do espírito construir o desenvolvimento pelo qual a consciência empírica pode chegar até este elemento, o que resgata, por sua vez, a exigência de identidade levantada na Differenzschrift em face da filosofia transcendental. "A razão, que encontra a consciência presa em particularidades, somente se torna especulação

18 Para uma reconstrução deste desenvolvimento (DÜSING, K. Die Entstehung des spekulativen idealismus. In: JAESCHKE, W. Transzendentalphilosophie und Spekulation. Hamburg: Felix Meiner, 1994), (GILBERT, G. Critique et dialectique: l'itinéraire de Hegel à Iéna, (1801 1805). Bruxelles: Facultés Universitaires Saint-Louis, 1982) e (BAUM, M. Die Entstehung der Hegelschen Dialektik. Bonn: Bouvier, 1989).

19 "Se o absoluto é o que se intui a si mesmo... e aquela intuição absoluta e este autoconhecer, aquela expansão infinita e este infinito recolher-se da mesma são, em si mesmos, pura e simplesmente um, então, se ambos são reais enquanto atributos, o espírito é mais elevado que a natureza; pois, se esta é o absoluto auto-intuir-se e a efetividade da mediação infinitamente indiferenciada e do desdobramento, então o espírito, o qual é o intuir de si mesmo enquanto de si mesmo ou o conhecer absoluto, no recolher do universo (a)dentro de si mesmo, é tanto a totalidade rompida (auseinandergeworfene Totalität) desta multiplicidade, sobre a qual ele se estende, como também a idealidade absoluta da mesma, na qual ele nadifica este [ir] para fora um do outro e reflete (a)dentro de si enquanto [(a)dentro] do ponto imediato de unidade do conceito infinito" (HEGEL, 1970, II, p. 502). 
filosófica por meio disso: que ela se eleve a si mesma e somente se confie a si mesma e ao absoluto, o qual é, ao mesmo tempo, seu objeto. Ela não arrisca nisso nada além de finitudes da consciência e, para ultrapassá-las e construir o absoluto na consciência, ela se eleva à especulação e apreendeu (hat ergriffen), em si mesma, sua própria fundamentação na ausência de fundamento (Grundlosigkeit) das limitações e peculiaridades" (HEGEL, 1970, II, p. 18).

Recordamos que, depois de ter exposto as insuficiências da filosofia fichteana em termos de uma teoria da consciência (HEGEL, 1970, II, p. 52-53), Hegel acaba por criticar a filosofia social de Fichte pela separação irreconciliável entre consciência empírica e consciência pura e propõe, baseado na noção schelliniana de intuição intelectual, a qual tem de abarcar a atividade separadora da reflexão e a intuição da unidade dos contrapostos, que autoconsciência pura seja compreendida como fonte da multiplicidade de determinações da consciência empírica. "Na intuição transcendental toda contraposição está suspensa, toda diferença entre a construção do universo através da e para a inteligência e a sua organização que aparece como independente, que é intuída como um objetivo, [está] nadificada. O produzir da consciência desta identidade é a especulação, e porque idealidade e realidade são nela um, ela é intuição" (HEGEL, 1970, II, p. 42). Tal ideário, quando compreendido sob a luz do desenvolvimento do conceito de eticidade, revela a insuficiência da exposição pretendida por Hegel no Naturrechtsaufsatz e no System der Sittlichkeit, a qual não é capaz de comprovar a unidade entre consciência pura e consciência empírica na própria consciência individual.

Para Hegel, no Naturrechtsaufsatz, o que propriamente constitui o "caráter mais elevado" do espírito em relação à natureza -e, por conseguinte, também da natureza ética em face da natureza física - é que aquele se estrutura pela inteligência compreendida enquanto conceito absoluto, isto é, negatividade absoluta, capaz de passar da absoluta singularidade à absoluta universalidade (HEGEL, 1970, II, p. 478), o que Hegel compreendera como indiferenciação da singularidade. Assim, o princípio puro da identidade, enquanto possibilidade de se reverter no contrário imediato de si mesmo, é, como conceito verdadeiro da infinitude (HEGEL, 1970, II, p. 453-501), munido do poder de produzir oposições, de ser uma diferenciação de si na simples auto-referência, dispersão na multiplicidade e recolhimento desta na unidade.

Já no System der Sittlichkeit, também a inteligência concebida desta forma desempenha um papel imprescindível, pois a eticidade absoluta aparece primeiro como natureza, isto é, dispersão na multiplicidade dos indivíduos independentes e de suas ações, a qual é suspensa pela negatividade 
da inteligência. "Os olhos do espírito e os olhos do corpo coincidem perfeitamente" (HEGEL, 2002, p. 48). É somente mediante uma autosuspensão da individualidade que surge a eticidade absoluta em sua expressão imediata e na forma espiritual dos costumes e instituições de um povo. "O conceito absoluto em sua completa indeterminidade, a inquietação da infinitude do conceito absoluto, que nada mais é o do que isto, e no seu nadificar dos contrapostos um pelo outro, nadifica a si mesmo, o ser-real da subjetividade absoluta" (HEGEL, 2002, p. 38). Do ponto de vista da evolução da concepção hegeliana do movimento da eticidade e do projeto de mediação entre filosofia política antiga e filosofia transcendental, a insuficiência do System der Sittlichkeit está, sobretudo, em que Hegel somente possui o método da subsunção recíproca e da adequação entre conceito e intuição, implementação do princípio metodológico de unificação entre reflexão e intuição defendido na Differenzschrift, para fazer a mediação entre a consciência da absoluta eticidade, isto é, entre o espírito de um povo e a consciência da singularidade, que é como aparece, primeiramente, a inteligência. A comprovação textual desta ancoragem metodológica da unidade ética reside na apresentação do principal nexo teórico do System der Sittlichkeit, a suspensão da singularidade na eticidade absoluta, na terminologia de uma teoria da consciência estruturada pela inteligência enquanto conceito absoluto. ${ }^{20}$

Para Hegel, "a consciência empírica e não-ética" relaciona-se à consciência universal, "o ser-um do universal e do particular do qual aquela é o fundamento" (HEGEL, 2002, p. 48), de tal maneira que, na existência ética do indivíduo no povo, "emergiu para a consciência a identidade absoluta, a qual era antes a [identidade] da natureza e algo interior" (HEGEL, 2002, p. 49). Neste registro da vida ética - em que Hegel vislumbra conseqüências

20 "A eticidade é... determinada, que o indivíduo vivo enquanto vida seja igual ao conceito absoluto, que sua consciência empírica seja um com a [consciência absoluta e a consciência absoluta [seja] ela mesma consciência empírica, uma intuição indiferenciável de si mesma; porém, de tal maneira que esta diferenciação seja completamente algo superficial e ideal, e o ser-sujeito seja na realidade, e na diferenciação nada seja. Este completo ser-igual é somente possível pela inteligência, ou conceito absoluto, segundo o qual o ser vivo, enquanto contrário de si mesmo, é como objeto. Este objeto é ele mesmo vivacidade absoluta e absoluta identidade do uno e do múltiplo, não como toda outra intuição empírica posta sob a relação, a qual, servindo à necessidade e enquanto limitado, está posta [como] tendo exterior a si a infinitude" (HEGEL, 2002, p. 48). 
relacionadas ao seu posterior conceito de espírito absoluto, ${ }^{21} \mathrm{o}$ qual se diferencia, já em Jena, do "espírito objetivo" das instituições da eticidade -, "o particular, o indivíduo, é, enquanto consciência particular, pura e simplesmente igual ao universal" (HEGEL, 2002, p. 49). Desta maneira, na medida em que a "consciência é o infinito, o conceito absoluto, na forma da unidade", tal conceito está posto na consciência empírica somente como relação e "a unidade deles é, enquanto tal, uma [unidade] oculta" (HEGEL, 2002, p. 50).

Por um lado, na eticidade, "esta separação é, para a própria consciência empírica, uma determinidade ideal. Ela reconhece, no contraposto, o objeto, absolutamente o mesmo que é o sujeito. Ela intui a mesmidade (Dieselbigkeit)" (HEGEL, 2002, p. 50); por outro lado, na relação, a unidade dos contrapostos "aparece em ambos ... sob a forma da possibilidade de serem repartidos (numa consciência), e a efetividade do ser-partido é justamente a contraposição" (HEGEL, 2002, p. 50). Com efeito, se se considera que o ambiente em que o absoluto aparece na eticidade é a consciência e que, portanto, o System der Sittlichkeit procura mostrar que a consciência singular somente chega à sua verdade no ser-um das individualidades, o método de subsunção revela-se exterior ao processo da consciência inicial, na medida em que não mostra a relação essencial entre a consciência individual e a consciência ética enquanto autoconhecimento da essência: a subsunção revela-se como um meio exterior de indiferenciar termos contrapostos que são, por definição, a possibilidade de serem repartidos numa consciência.

"Hegel não é capaz, no Sistema da Eticidade, de apresentar a passagem das formas da eticidade "natural" e "negativa" para a verdadeira eticidade enquanto um progresso necessário que esteja fundado na "natureza" da própria eticidade relativa, e isto significa: no seu elemento e sustentáculo (Träger), a consciência singular. A "consciência empírica" permanece presa nos limites da "relação" e de sua negação incompleta e unilateral" (SIEP, 1979, p. 181). Portanto, a insuficiência não pode ser diretamente resolvida apenas apelando à essência auto-referente e autodiferenciadora do conceito absoluto,

21 "A perspectiva que a filosofia tem do mundo e da necessidade, segundo a qual todas as coisas estão em Deus e não há nenhuma singularidade, está perfeitamente realizada para a consciência empírica, ao ter cada singularidade do agir ou pensar ou ser, sua essência e seu significado apenas e tão-somente no todo, e nesta medida o fundamento dela [é] pensado, somente isto é pensado, e o indivíduo não sabe de nenhum outro" (HEGEL, 2002, p. 48) "esta universalidade, a qual unificou a particularidade pura e simplesmente consigo, é a divindade do povo, e este universal, intuído na forma ideal da particularidade, é o Deus do povo: ele é uma maneira ideal de intuí-lo" (HEGEL, 2002, p. 49). 
pois isso significaria apenas uma pressuposição da unidade entre a consciência empírica e a consciência absoluta, e não sua comprovação direta para a consciência individual: é preciso que o processo pelo qual a eticidade substancial se origina e os elementos socializantes envolvidos neste processo gradativo sejam apresentados na forma de um progredir imanente à própria consciência.

É justamente a questão de transformar o processo de subsunção da eticidade natural na eticidade absoluta em um movimento de auto-efetivação do próprio absoluto que conduz Hegel à elaboração de uma teoria da consciência como sustentáculo da filosofia do espírito, uma teoria da consciência que encontra sua mais alta decantação já em um contexto um tanto diferente do problema específico do movimento da eticidade, sobre o qual se debruçara Hegel entre 1803 e 1806, a saber: na "ciência da experiência da consciência", que é como se apresenta a Fenomenologia de 1807.

É no primeiro contexto que o conceito de reconhecimento adquire enorme importância, justamente ao tornar experienciável à própria consciência individual como ela, enquanto totalidade para si, suspende a si mesma na identidade com o espírito do povo. Em vista deste novo registro, ao qual a teoria hegeliana da eticidade chega a partir de 1803, o movimento da consciência individual em direção ao espírito ético do povo ganha a feição de um desenvolvimento dotado de uma necessidade interior, inscrito na estrutura da própria consciência individual. Mas a ubiqüidade da consciência e de suas formas no mundo de objetivação espiritual não implica per se redução da importância da mediação intersubjetiva para a formação da consciência, de maneira que deve ser melhor compreendida a distinção estabelecida por Honneth entre a formação da consciência e a aquisição por ela de níveis de autocompreensão compatíveis com os estágios de sua existência social e objetiva. O processo de formação da consciência pode muito bem ser considerado condição para aquela aquisição.

Embora a discussão deste núcleo exija um exame da passagem entre a potência da família e a luta por reconhecimento, que conduz ao espírito ético, pode-se ver que é neste contexto original que Hegel vislumbra a possibilidade de implementar a mediação entre o princípio moderno da singularidade livre e o quadro institucional de uma eticidade substancial inspirada na pólis - compreendendo-o agora, entretanto, na medida em que a perspectiva da própria consciência individual acerca do processo conceitual por que passa para se constituir como comunidade "adquire seu direito", explicitamente como uma imbricação de individualização e socialização. A partir do processo de reconhecimento, a consciência é determinada como 
movimento de fazer a experiência de si mesma no outro enquanto individualidade, formando-se, concomitantemente, como consciência universal.

\section{Conclusão - articulação preliminar entre consciência e espírito ético: unidade de universalidade e singularidade nos Jenaer Systementwürfe 1803/04}

Viu-se acima que Hegel já tem em mãos, em 1802, o princípio fundamental a ser operacionalizado na teoria da consciência: a inteligência, cuja essência é, enquanto conceito absoluto, poder passar ao contrário imediato de si. Justamente a pormenorização, para a própria consciência individual, do processo pelo qual ela passa da singularidade à universalidade, isto é, vê sua singularidade sendo gradativamente suspensa até desembocar na união comunitária com outras consciências singulares, é a intuição fundamental do vínculo que Hegel pretende estabelecer entre teoria do reconhecimento e teoria da consciência (SIEP, 1979, p. 180).

É verdade que os elementos exteriores deste processo de uma "socialização individualizante" já se tornaram claros no System der Sittlichkeit, na medida em que um significado concreto da singularidade individual sempre se vinculara a formas societárias de existência, ainda em um nível pré-estatal. Fazendo da consciência o elemento no qual o espírito se desenvolve, em direção ao autoconhecimento absoluto, enquanto reabsorção da idéia que se exteriorizou na filosofia da natureza, o Systementwurf 1803/04 promove, prenunciando o sistema maduro, a inserção do desenvolvimento da eticidade em uma filosofia do espírito. Na medida em que "faz preceder à filosofia prática, compreendida enquanto filosofia da eticidade, uma derivação de seu objeto no âmbito da teoria da consciência, uma derivação que não é já componente do sistema da eticidade" (SCHNÄDELBACH, 2000, p. 139), ${ }^{22}$ Hegel acaba por tornar prescindível a pressuposição do télos do desenvolvimento da eticidade e a conseqüente exterioridade do método de reconstrução deste movimento.

${ }^{22}$ Schnädelbach impõe ressalvas à tese de Wildt de que a anteposição de uma teoria da consciência ao desenvolvimento da eticidade representa uma reaproximação de Fichte no período intermediário de Jena (WILDT, 1983). Hegel tenciona, desde o início, o programa do desenvolvimento do conceito de eticidade capaz de oferecer a mediação entre o princípio moderno da liberdade subjetiva e a eticidade substancial da pólis antiga. Assim, compreende que a eticidade somente possa ser conceitualmente restabelecida em um viés investigativo que rompa com o caráter absoluto da posição do sujeito transcendental. 
A diferenciação categórica entre espírito e natureza pode apenas em parte ser entendida como reabilitação da postura filosófico-transcendental (KIMMERLE, 1970, p. 260), ${ }^{23}$ uma vez que a gênese do espírito se dá aqui imanentemente a partir de nexos pertencentes à filosofia da natureza. Se, por um lado, a filosofia da natureza tem com isso seu término, e se, nestes termos, uma tal diferenciação rigorosa seria o ponto de acordo entre Hegel e a tradição transcendental; por outro lado, a filosofia do espírito não recorre simplesmente, como seu ponto de partida, a uma autoconsciência pura, mas antes à própria forma imediata do espírito: uma consciência efetiva, individual e que se constitui no âmbito formado pelas relações naturais suspensas pelo retorno a si do espírito a partir da exteriorização. Que o espírito seja qualitativamente diferente da natureza, eis o ponto comum de Hegel com Kant e Fichte; mas que, todavia, o ponto de partida para o desenvolvimento do espírito pressuponha o ambiente de conexões naturais suspensas no conceito de uma consciência efetiva, eis sua ruptura com eles. É na concepção da consciência como simultaneamente universal e individual que reside o cerne da tentativa de suspender a cisão fichteana entre consciência pura e consciência empírica. ${ }^{24}$

A consciência é o conceito que, introduzido por Hegel na sistemática da filosofia prática a partir de 1803, possibilita a unificação da filosofia do absoluto com a filosofia da inteligência numa filosofia do espírito (KIMMERLE, 1970, p. 256). Nos fragmentos 15 a 17, torna-se mais claro como

${ }^{23}$ Para Kimmerle, o momento da introdução do conceito de consciência na filosofia do espírito representa o ponto de inflexão no desenvolvimento da filosofia hegeliana, uma reabilitação do princípio da filosofia transcendental como conceito central da filosofia, com a ressalva de que a unidade de sujeito e objeto é tematizada na dimensão do espírito aparecente (SCHNÄDELBACH, 2000, p. 139).

${ }^{24} \mathrm{O}$ que caracteriza, segundo Habermas, a Wissenschaftslehre de Fichte é a ralação dialética entre eu e outro perseguida nos limites da subjetividade do saber-de-si, pelo que permaneceria vinculada à relação da "reflexão solitária". Habermas parece ignorar totalmente os desenvolvimentos contidos na Grundlage des Naturrechts. A gênese intersubjetiva da autoconsciência individual poderia, sem dúvida, ser interpretada como preâmbulo à concepção hegeliana da dialética da autoconsciência, a qual de fato ultrapassa a relação da reflexão solitária na direção de uma relação complementar de indivíduos que se reconhecem. O legado fichteano de uma gênese da autoconsciência pela mediação interativa conduziu Hegel ao abandono dos métodos de fundamentação da filosofia transcendental da consciência e à opção por uma teoria do espírito, o qual se constitui como medium da comunicação e da constituição recíproca da identidade dos parceiros (HABERMAS, J. Individuierung durch Vergesellschaftung. In: Nachmetaphysisches Denken. Frankfurt am Main: Suhrkamp, 1988). Em nossa opinião, a teoria fichteana do reconhecimento se encontra entre os motivadores da teoria hegeliana do espírito como desdobramento dialético do eu enquanto unidade de universalidade e singularidade (LIMA, 2006). 
a consciência está envolvida na passagem imanente da natureza para o espírito, tanto sua diferenciação quanto no desdobramento de suas "figuras". "O conceito assim determinado do espírito é a consciência enquanto o conceito do ser-um do simples e da infinitude (als der Begriff des Einseins des Einfachen und der Unendlichkeit). Mas, no espí/rito, ela existe para si mesma ou enquanto verdadeira infinitude; o contraposto nela, na infinitude, é esta absoluta simplicidade de ambos mesmos. Este conceito de espírito é aquilo que se chama consciência" (HEGEL, 1986, p. 183-184). Consciência e espírito estão em uma relação interna de mútua determinação: a consciência é "apenas" o conceito da identidade da unidade e da infinitude, o qual somente na infinitude do espírito é "para si", unidade absoluta dos contrapostos.

Em tais fragmentos, "a essência da consciência é ...", "a primeira forma da existência do espírito é a consciência em geral ..." e "é somente a forma ...", nos quais Hegel promove suas primeiras considerações sistemáticas sobre o conceito de consciência, são desenvolvidas caracterizações gerais que se deixam conduzir ao princípio básico de que os dois "lados" da consciência, das Bewusstseiende e das, dessen es sich bewusst ist, são imediatamente um e, por isso, constituem a forma da universalidade.

A essência (das Wesen) da consciência é que ela seja imediatamente, em uma identidade etérea, unidade absoluta da oposição. Ela somente pode ser isso ao ser ela mesma, imediatamente, na medida em que ela é contraposta, ambos os membros da oposição, sendo neles simplesmente, enquanto membros da oposição, imediatamente o contrário de si mesma, a diferença absoluta, a diferença que se suspende a si mesma e que é suspensa. Nesta unidade da oposição, o que é consciente (das Bewusstseiende) é um dos lados da mesma; e aquilo de que se é consciente (das, dessen es sich bewusst ist), o outro lado. Ambos são essencialmente o mesmo, ambos [são] uma unidade imediata da singularidade e da universalidade. (HEGEL, 1986, p. 189).

É a estrutura da consciência que torna possível a caracterização do espírito como combinação de universalidade e particularidade, de idealidade e realidade. Neste contexto, singularidade significa uma unidade de universalidade e particularidade, na qual a multiplicidade do particular é negada e, ao mesmo tempo, conservada, de maneira que universalidade é compreendida não como uma unidade universal abstrata, mas como um universal internamente diferenciado. O universal diferenciado é a estrutura da consciência, determinada como unidade da singularidade, isto é, da unidade 
negativa do universal abstrato e da multiplicidade universal posta em si. Tratase, portanto, da unidade do conceito determinado de maneira imanente. A assimilação hegeliana da teoria da consciência é, assim, a transformação da consciência em uma unidade previamente articulada da consciência e daquilo de que se é consciente, isto é, como autoconsciência. ${ }^{25}$

Com efeito, tal compreensão, que antecipa quase textualmente o início do segundo tomo da Fenomenologia do Espírito, pauta-se pela unidade dialética de consciência e autoconsciência, ainda em sua forma imediata (WILDT, 1983, p. 330). "A consciência é, enquanto o que é consciente de si mesmo a partir de si enquanto consciência, a identidade ativa e negante (die tätige negierende Identität), a qual retorna a si a partir do seu tornar-se-consciente de um outro que não ela mesma, e suspende este outro através do passar a este outro" (HEGEL, 1986, p. 189). Enquanto unidade imediata de universalidade e singularidade, da indeterminidade enquanto totalidade e da determinidade - e também sua contraposição imediatamente suspensa-, a consciência é tanto consciência do objeto, como consciência de si mesma como consciente do objeto (suspensão da primeira contraposição), como ainda o movimento de passagem (e de suspensão da contraposição) entre consciência e autoconsciência. "Mas, da mesma forma, a própria consciência [é] o contrário imediato e simples de si mesma, uma vez o contraposto daquilo de que se é consciente, separando-se em ativo e passivo; outra vez o contrário desta separação, o absoluto ser-um da diferença, o ser-um da diferença que é e da diferença suspensa (das Einssein des seienden und des aufgehobenen Unterschiedes)" (HEGEL, 1986, p. 184). A consciência é concebida, enquanto estágio e elemento do desenvolvimento do espírito, segundo a dupla oposição ser/devir e atividade/passividade, e de tal forma que, enquanto devir ou desenvolvimento, a consciência é oposição entre atividade e passividade e, enquanto ser ou estágio de desenvolvimento, é unidade de ambos. Nesse sentido, Hegel compreende a consciência também como unidade de simplicidade (Einfachheit), isto é, relação imediata a si ou separação suspensa, e de infinitude, ou seja, contrário de si mesma, separação que permanece na unidade consigo mesma.

25 Para uma bela caracterização desta estrutura espiritual, prefigurada na concepção de Mitte, ver a discussão proposta por Habermas (HABERMAS, J. Wege der Detranzendentalisierung: Von Kant zu Hegel und züruck. In: Aufsätze. Frankfurt am Main: Suhrkamp, 1999). 
Para Hegel, ainda que sua essência seja "igualmente o ser-suspenso de ambos" (HEGEL, 1986, p. 189), a consciência aparece, imediatamente, como um de seus lados, "o qual é ele mesmo determinado como o ativo (als Tätiges) e, por isso, como o que suspende (als Aufhebendes)" (HEGEL, 1986, p. 189); e, nesse sentido, como algo que não "põe a si mesmo somente como consciência, não como aquilo de que se é consciente, e é, portanto, consciência somente singular, formal, negativa, e não absoluta. Pois aquilo de que é consciente ela não põe como igual a si” (HEGEL, 1986, p. 189). Na medida em que a consciência se põe somente como o primeiro lado, a forma do consciente é determinada pelo exterior, sendo por isso empírica.

Esta / consciência empírica tem, entretanto, de ser consciência absoluta, ou imediatamente o outro que não o que ela é, tem de ter em si mesma seu ser-outro (sein Anderssein), sua igualdade positiva com a consciência. Ela é consciência absoluta ao ser este outro que ela mesma não é, sua própria consciência perfeita, sem qualquer ser-para-si-mesma, sem qualquer verdadeira diversidade, diversa dele somente pela forma sem conteúdo do ser-outro, de maneira que ela, na medida em que é tão semconteúdo quanto forma, é universalmente nela mesma também ideal. (HEGEL, 1986, p. 189-190).

A consciência, que tem imediatamente a "igualdade consigo mesma (Selbstgleichheit)" (HEGEL, 1986, p. 189) somente de um modo negativo, "somente é consciência, na medida em que se contrapõe a si como um outro" (HEGEL, 1986, p. 189), de maneira que traz inscrita em sua essência o motor de seu movimento e "tem de deixar entrar no lugar do outro um outro que lhe é desigual; ela suprime este outro desigual, mas chega por meio disso somente a uma infinitude empírica e exterior, a qual tem seu outro sempre exterior a si" (HEGEL, 1986, p. 189). Télos e desdobramento do espírito se estabelecem: trata-se do rompimento absoluto da contraposição, do "para si" da infinitude exterior em direção à posição de si neste ser-outro. Por conseguinte, o desenvolvimento da consciência em direção à sua plenificação como espírito passa por estágios de auto-reflexão que se constituem cada um, primeiramente, pela posição de uma separação pela e na consciência como atividade; em segundo lugar, a consciência suspende, pela apreensão de si mesma como contradição, a identidade de si mesma; e atinge, em terceiro lugar, mediante uma reflexão de si mesma em si mesma, um estágio superior na progressão.

"A inteira consciência, esta unidade da singularidade, da unidade negativa e da multiplicidade universal posta em si, do conceito indeterminado, 
tem de se elevar à singularidade absoluta, elevar esta última como tal à totalidade e, a partir deste configurar-a-si-mesmo (aus diesem Sichselbstgestalten), o indivíduo passa, da mesma forma, ao seu contrário" (HEGEL, 1986, p. 187). Acontece que, para Hegel, a consciência é, desde o princípio, universal singularizado, ainda que não se saiba a si mesma como tal, e, por conseguinte, como a estrutura formal da consciência não se refere a uma consciência em geral, mas sempre a uma consciência singular, a realização do nexo formal consiste no desenvolvimento, a partir de uma determinação abstrata da consciência singular, em direção à singularidade absoluta, que traz implícita em sua formulação, enquanto conceito, uma unidade da universalidade e da singularidade dispersa nas consciências singulares de indivíduos efetivos. "Na medida em que o conceito de espírito é ser-um absoluto da singularidade absoluta - para a multiplicidade como algo negado (ein Negiertes) - e da absoluta multiplicidade - a qual é multiplicidade positiva ou multiplicidade simples em si mesma universal (die als positive oder selbst an sich allgemeine einfache Vielheit) -, então este conceito tem de se realizar" (HEGEL, 1986, p. 187). É a esta singularidade universal que Hegel confere a designação de espírito do povo, ao passo que a particularidade refere-se à multiplicidade dos indivíduos singulares que vivem e agem nele.

Em seu estar-suspenso está somente o espírito vivo do povo, seu ser-suspenso é para elas mesmas, ele é em si a consciência de cada um, também na medida em que ele é um singular e assim aparece. Ele existe, ao mesmo tempo, como algo deles diverso, intuível (ein von ihnen Verschiedenes, Anschaubares), enquanto um ser-outro (ein Anderssein) dos indivíduos, do que eles são; mas de tal forma que este seu ser-outro é ele mesmo absolutamente universal para os próprios indivíduos. (HEGEL, 1986, p. 188).

Ao contrário do que se dá no System der Sittlichkeit e no Naturrechtsaufsatz, a unidade ética do povo é tratada aqui como um objeto a ser construído por meio de um desenvolvimento vinculado à teoria da consciência. "Ele existe como objeto (Gegenstand) de sua consciência singular, enquanto um exterior, no qual eles, tal como são nele absolutamente um, se desligam (sich abscheiden) e são para si. É a unidade universal e o meio absoluto (absolute Mitte) dela, e onde eles estão postos idealmente, enquanto suspensos; e este seu estar-suspenso (dies ihr Aufgehobensein) é, ao mesmo tempo, para eles mesmos" (HEGEL, 1986, p. 188). É esta ligação do conceito do espírito com a teoria da consciência que prepara, na forma da distinção entre as determinações subjetivas da individualidade efetiva e a organização ou 
autoconfiguração do espírito, a distinção entre espírito subjetivo e espírito objetivo (SCHNÄDELBACH, 2000, p. 119). ${ }^{26}$

Nesse sentido, o movimento que define a filosofia do espírito - e, com ela, também a filosofia prática - nos Systementwürfe 1803/04 é o movimento pelo qual a consciência vai paulatinamente apreendendo aquilo de que é consciente como sendo ela mesma, tornando-se, ao término do movimento, realidade absoluta da consciência, o contrário do que ela imediatamente é. "Este é o fim, a realidade absoluta da consciência, à qual nós temos de elevar seu conceito. É a totalidade que ela tem enquanto espírito de um povo, o qual é absolutamente a consciência de todos, que eles intuem (anschauen) e que contrapõem a si enquanto consciência, mas, do mesmo modo, conhecem imediatamente sua contraposição, sua singularidade como individualidade nele suspensa, ou sua consciência como um absolutamente universal" (HEGEL, 1986, p. 190).

O desenvolvimento do espírito desde a sua célula - a consciência não como a "autoconsciência pura" de Fichte, mas como unidade imediata da universalidade e singularidade -, coincide com o movimento de auto-suspensão da singularidade, um processo cuja característica propriamente filosófico-social, o descentramento da perspectiva individualista da singularidade excludente, será amplamente realçada pela teoria do reconhecimento. Somente no povo, ao ser suspensa como singular, a atividade consciente adquire existência duradoura, tornando-se universalidade de uma obra comum. "como lá [em seu contrário E.C.L] o conceito absoluto da consciência existe como singularidade absoluta, [ele tem] aqui de existir como conceito determinado, ou como em si

26 Pode-se dizer que Hegel passa a distinguir claramente entre o (auto-)conhecimento da autoconfiguração espiritual da comunidade ética como uma esfera separada em relação às faculdades abstratas ou individuais do espírito, as quais constituem sua relação a si mesmo. "Conhecendo a organização do espírito, então nós conhecemos a consciência não como o simplesmente interior dos indivíduos, ou como os momentos da oposição (die Momente des Gegensatzes) aparecem nos indivíduos como tais, como múltiplas faculdades, inclinações e paixões etc., que se referem a objetos particulares enquanto conceitos determinados; e sim, ao conhecer a consciência em geral, segundo seu conceito, enquanto absoluto Uno da singularidade e do conceito determinado, então nós conhecemos justamente seus momentos organizantes (seine organisierenden Momente), tal como eles, enquanto momentos da consciência absoluta, são para si, não como algo que estivesse simplesmente na forma do indivíduo, de um dos lados da consciência absoluta - enquanto paixão, impulso, inclinação -; mas como ela é absolutamente para si, e se organiza para si mesma - e dessa forma, a propósito, está nos indivíduos, mas imediatamente como seu outro lado, aquilo a que eles, enquanto indivíduos, se contrapõem. No entanto, a consciência é a essência (Wesen) de ambos" (HEGEL, G. W. F. Jenaer Systementwürfe I. Hamburg: Felix Meiner, 1986, p. 188). 
essencialmente um diversificado (ein Vielfaches), exterior, e condensar-se, a partir de ambos, passando à absoluta totalidade, de tal forma que, igualmente, um grande indivíduo universal exista enquanto espírito de um povo, o qual [é] absolutamente enquanto um Sendo nos indivíduos (das absolut als ein in den Individuen Seiendes), - os quais são suas singularidades, / seus órgãos; também, como, justamente nisso, contraposto a eles" (HEGEL, 1986, p. 187-188).

Na medida em que a essência da consciência é a unidade dialética de si mesma e de seu outro, isto é, de sua atividade e de sua passividade, a consciência que é espírito absoluto, espírito de um povo, põe sua atividade na mesma medida em que a põe suspensa como passividade. A unidade dos dois elementos da consciência é a unidade de sujeito e objeto da qual a filosofia do espírito parte enquanto não desdobrada, e para a qual ela retorna, mas agora na forma de um "espírito ético" enquanto autoconhecimento do espírito, uma apresentação real da idéia na unidade absoluta de universal e particular.

\section{Referências}

BAUM, M. Die Entstehung der Hegelschen Dialektik. Bonn: Bouvier, 1989.

DÜSING, K. Die Entstehung des spekulativen idealismus. In: JAESCHKE, W. Transzendentalphilosophie und Spekulation. Hamburg: Felix Meiner, 1994.

Spekulation und Reflexion. Zur Zusammenarbeit Schellings und Hegels in Jena. In: HST, v. 5, n. 1969, p. 95-128, 1969.

FORST, R. Kommunitarismus und Liberalismus: Stationen einer Debatte. In: HONNETH, A. Kommunitarismus und Liberalismus: eine Debatte über die moralischen Grundlagen moderner Gesellschaften. Frankfurt am Main: Campus, 1995.

GILBERT, G. Critique et dialectique: l'itinéraire de Hegel à Iéna, (18011805). Bruxelles: Facultés Universitaires Saint-Louis, 1982.

GADAMER, H. G. Hegels Dialektik des Selbstbewußtseins. In: FULDA, H. Materialen zu Hegels "Phänomenologie des Geistes". Frankfurt am Main: Suhrkamp, 1992.

HABERMAS, J. Arbeit und Interaktion. Bemerkungen zu Hegels Jenenser 'Philosophie des Geites'. In: GÖHLER, G. Frühe Politische Systeme. Frankfurt am Main: Ullstein, 1974. 
Individuierung durch Vergesellschaftung. In: Nachmetaphysisches

Denken. Frankfurt am Main: Suhrkamp, 1988.

.Wege der Detranzendentalisierung: Von Kant zu Hegel und züruck.

In:__. Wahrheit und Rechtfertigung: Philosophische Aufsätze. Frankfurt am Main: Suhrkamp, 1999.

HEGEL, G.W.F. Werke in 20 bände. Frankfurt am Main: Suhrkamp, 1970.

Jenaer Systementwürfe I. Hamburg: Felix Meiner, 1986.

Fenomenologia do espírito. São Paulo: Loyola, 1992.

Enciclopédia das ciências filosóficas. São Paulo: Loyola, 1995

System der Sittlichkeit [Critik der Fichteschen Naturrechts].

Hamburg: Felix Meiner, 2002.

HONNETH, A. Kampf um Anerkennung: zur moralischen Grammatik sozialer Konflikte. Frankfurt am Main: Suhrkamp, 1992.

. Zwischen Aristoteles und Kant: Skizze einer Moral der Anerkennung. In: HONNETH, A. Das Andere der Gerechtigkeit: Aufsätze zur Praktischen Philosophie. Frankfurt am Main: Suhrkamp, 2000.

Gerechtigkeit und Kommunikative Freiheit: Überlegungen im Anschluss an Hegel. In: MERKER, B. Subjektivität und Anerkennung. Frankfurt am Main: Mentis, 2004.

KIMMERLE, H. Das problem der abgeschlossenheit des denkens. Hegels “System der Philosophie" in den Jahren 1800-1804. Bonn: H. Bouvier, 1970.

LIMA, E. C. Direito e intersubjetividade: eticidade moderna em Hegel e o conceito fichteano de reconhecimento. 2006. 293 f. Tese (Doutorado em Filosofia) - UNICAMP, Campinas, 2006.

Direito, intersubjetividade e educação: sobre a leitura hegeliana do Naturrecht de Fichte. Doispontos, Curitiba, v. 2, n. 2, p. 63-106, 2007.

PATTEN, A. Hegel's idea of freedom. New York: Oxford University Press, 1999.

RIEDEL, M.; Hegels K. des N. In: RIEDEL, M. Studien zu Hegels Rechtsphilosophie. Frankfurt am Main: Suhrkamp, 1969. 
SCHNÄDELBACH, H. Hegels Praktische Philosophie: ein Kommentar der Texte in der Reihenfolge Ihrer Entstehung. Frankfurt am Main: Suhrkamp, 2000.

SIEP, L. Anerkennung als Prinzip der Praktischen Philosophie. Freiburg; München: Alber, 1979.

Der Freiheitsbegriff der praktischen Philosophie Hegels in Jena. In: SIEP, L. Praktische Philosophie im Deutschen Idealismus. Frankfurt am Main: Suhrkamp, 1992.

Die Bewegung des Anerkennens in der Phänomenologie des Geistes. In: KÖHLER, D.; HEGEL, G. W. F. Phänomenologie des Geistes. Berlin: Akademische Verlag, 1998.

Der Weg der Phänomenologie des Geistes. Ein Einführender Kommentar zu Hegels "Differenzschrift" und "Phänomenologie des Geistes”. Frankfurt am Main: Suhrkamp, 2000.

THEUNISSEN, M. Die Verdrängte Intersubjektivität in Hegels Philosophie des Rechts. In: D. HENRICH, D.; HORSTMANN, R. P. (Ed.). Hegels Philosophie des Rechts: Die Theorie der Rechtsformen und Ihre Logik. Stuttgart: Klett-Cotta, 1982a.

WILDT, A. Autonomie und anerkennung. Hegels moralitätskritik im lichte seiner fichte-rezeption. Stuttgart: Klett-Cotta, 1983.

WILLIAMS, R. Hegel's ethics of recognition. Los Angeles: University of California Press, 1997.

Recebido: 14/01/2008

Received: 01/14/2008

Aprovado: $23 / 02 / 2008$

Approved: 02/23/2008 